\title{
Validation List no.144 List of new names and new combinations
previously effectively, but not validly, published
}

Correspondence Jean Euzéby email address can be found at www.bacterio.net
The purpose of this announcement is to effect the valid publication of the following effectively published new names and new combinations under the procedure described in the Bacteriological Code (1990 Revision). Authors and other individuals wishing to have new names and/or combinations included in future lists should send three copies of the pertinent reprint or photocopies thereof, or an electronic copy of the published paper, to the IJSEM Editorial Office for confirmation that all of the other requirements for valid publication have been met. It is also a requirement of IJSEM and the ICSP that authors of new species, new subspecies and new combinations provide evidence that types are deposited in two recognized culture collections in two different countries. It should be noted that the date of valid publication of these new names and combinations is the date of publication of this list, not the date of the original publication of the names and combinations. The authors of the new names and combinations are as given below, and these authors' names will be included in the author index of the present issue. Inclusion of a name on these lists validates the publication of the name and thereby makes it available in bacteriological nomenclature. The inclusion of a name on this list is not to be construed as taxonomic acceptance of the taxon to which the name is applied. Indeed, some of these names may, in time, be shown to be synonyms, or the organisms may be transferred to another genus, thus necessitating the creation of a new combination.

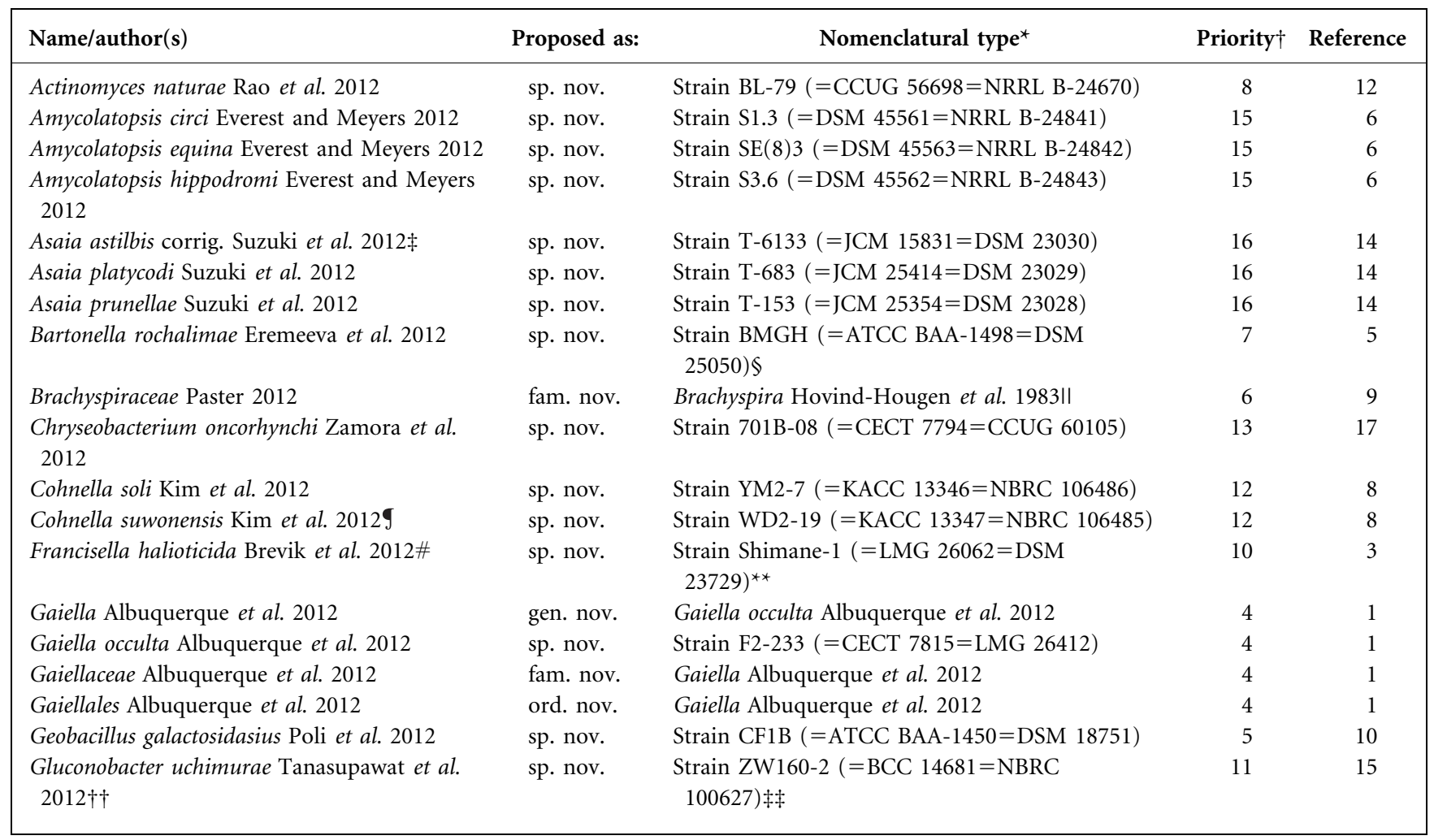


cont.

\begin{tabular}{|c|c|c|c|c|}
\hline Name/author(s) & Proposed as: & Nomenclatural type ${ }^{\star}$ & Priority $\dagger$ & Reference \\
\hline $\begin{array}{l}\text { Microbacterium suwonense Anandham et al. } \\
2012\end{array}$ & sp. nov. & $\begin{array}{l}\text { Strain M1T8B9 }(=\text { KACC } 14058=\text { NBRC } \\
\text { 106310) }\end{array}$ & 1 & 2 \\
\hline Natronoflexus Sorokin et al. 2012 & gen. nov. & $\begin{array}{l}\text { Natronoflexus pectinivorans Sorokin et al. } \\
2012\end{array}$ & 2 & 13 \\
\hline Natronoflexus pectinivorans Sorokin et al. 2012 & sp. nov. & Strain AP1 (=DSM 24179=UNIQEM U807) & 2 & 13 \\
\hline $\begin{array}{l}\text { Phascolarctobacterium succinatutens Watanabe } \\
\text { et al. } 2012\end{array}$ & sp. nov. & Strain YIT 12067 (=DSM 22533=JCM 16074) & 14 & 16 \\
\hline $\begin{array}{l}\text { Sphaerisporangium siamense Duangmal et al. } \\
2012\end{array}$ & sp. nov. & $\begin{array}{l}\text { Strain SR14.14 }(=\text { BCC } 41491=\text { NRRL } \\
\text { B-24805=NBRC 107570) }\end{array}$ & 9 & 4 \\
\hline Verrucosispora maris Goodfellow et al. 2012 & sp. nov. & $\begin{array}{l}\text { Strain AB-18-032 (=DSM } 45365=\mathrm{NRRL} \\
\text { B-24793) }\end{array}$ & 17 & 7 \\
\hline Vibrio plantisponsor Rameshkumar et al. 2012 & sp. nov. & $\begin{array}{l}\text { Strain MSSRF60 (=DSM 21026=LMG } \\
\text { 24470)\$\$ }\end{array}$ & 3 & 11 \\
\hline
\end{tabular}

For references to Validation Lists 1-71, see Int J Syst Bacteriol 49 (1999) 1325. Lists 72-143 were published in Int J Syst Evol Microbiol 50 (2000) 3 , 423, 949, 1415, 1699, 1953; and 51 (2001) 1, 263, 793, 1229, 1619, 1945; and 52 (2002) 3, 685, 1075, 1437, 1915; and 53 (2003) 1, 373, 627, 935, 1219, 1701; and 54 (2004) 1, 307, 631, 1005, 1425, 1909; and 55 (2005) 1, 547, 983, 1395, 1743, 2235; and 56 (2006) 1, 499, 925, 1459, 2025, 2507; and 57 (2007) 1, 433, 893, 1371, 1933, 2449; and 58 (2008) 1, 529, 1057, 1511, 1993, 2471; and 59 (2009) 1, 451, 923, 1555, 2129, 2647; and 60 (2010) 1, 469, 1009, 1477, 1985, 2509; 61 (2011) 1, 475, 1011, 1499, 2025, 2563; and 62 (2012) 1.

*Abbreviations of culture collections cited in this list can be found at http://ijs.sgmjournals.org/site/misc/collections.xhtml

$\dagger$ Priority number assigned according to the date the documentation and request for validation are received.

$\ddagger$ The original spelling of the specific epithet, astilbes (sic), has been corrected on validation according to Rule 61. The etymology of the epithet is the following: as.til'bis. N.L. n. Astilbes a generic name of saxifragaceous plant from which the type strain was isolated; N.L. gen. n. astilbis of Astilbes. \$The accession number DSM 25050 has been provided at the time of request for valid publication of the name.

IIIn the effective publication, the type genus is erroneously cited as Brachyspira aalborgi (sic).

The correct etymology of the specific epithet should be the following: su.won.en'sis. N.L. fem. adj. suwonensis of or belonging to Suwon region, Republic of Korea, where the type strain was first identified.

\#The correct etymology of the specific epithet should be the following: ha.li.o.ti.ci'da. N.L. n. Haliotis scientific name of a genus of abalone; L. suff. -cida (from L. v. caedo, to cut or kill) murderer, killer; N.L. n. (nominative in apposition) halioticida abalone killer, i.e. causing abalone mortality. ${ }^{* *}$ In the effective publication the strains LMG 26062 and DSM 23729 are cited as LMG26062 and DSM23729, respectively.

$\dagger \dagger$ The correct etymology of the specific epithet should be the following: u.chi.mu'ra.e. N.L. masc. gen. n. uchimurae of Uchimura, to honour a Japanese microbiologist, Dr Tai Uchimura, Professor, Tokyo University of Agriculture, Tokyo, Japan, in recognition of his contributions to the systematic study of acetic acid bacteria, especially in the study of Asaia, Acetobacter, Gluconobacter, and Gluconacetobacter strains.

\$The culture collection accession number PCU 264 is also cited in the effective publication, but the authors did not provide evidence that the type strain is deposited in this collection.

$\$ \$$ The culture collection accession number CAIM 1392 is also cited in the effective publication, but the authors did not provide evidence that the type strain is deposited in this collection.

\section{References}

1. Albuquerque, L., França, L., Rainey, F. A., Schumann, P., Nobre, M. F. \& da Costa, M. S. (2011). Gaiella occulta gen. nov., sp. nov., a novel representative of a deep branching phylogenetic lineage within the class Actinobacteria and proposal of Gaiellaceae fam. nov. and Gaiellales ord. nov. Syst Appl Microbiol 34, 595-599.

2. Anandham, R., Tamura, T., Hamada, M., Weon, H.-Y., Kim, S.-J., Kim, Y.-S., Suzuki, K. \& Kwon, S.-W. (2011). Microbacterium suwonense sp. nov., isolated from cow dung. J Microbiol 49, 852-856.

3. Brevik, Ø. J., Ottem, K. F., Kamaishi, T., Watanabe, K. \& Nylund, A. (2011). Francisella halioticida sp. nov., a pathogen of farmed giant abalone (Haliotis gigantea) in Japan. J Appl Microbiol 111, 10441056.

4. Duangmal, K., Mingma, R., Pathom-aree, W., Inahashi, Y., Matsumoto, A., Thamchaipenet, A. \& Takahashi, Y. (2011). Sphaerisporangium siamense sp. nov., an actinomycete isolated from rubber-tree rhizospheric soil. J Antibiot (Tokyo) 64, 293296.

5. Eremeeva, M. E., Gerns, H. L., Lydy, S. L., Goo, J. S., Ryan, E. T., Mathew, S. S., Ferraro, M. J., Holden, J. M., Nicholson, W. L. \& other authors (2007). Bacteremia, fever, and splenomegaly caused by a newly recognized Bartonella species. $N$ Engl J Med 356, 23812387.

6. Everest, G. J. \& Meyers, P. R. (2011). Evaluation of the antibiotic biosynthetic potential of the genus Amycolatopsis and description of Amycolatopsis circi sp. nov., Amycolatopsis equina sp. nov. and Amycolatopsis hippodromi sp. nov. J Appl Microbiol 111, 300311.

7. Goodfellow, M., Stach, J. E. M., Brown, R., Bonda, A. N. V., Jones, A. L., Mexson, J., Fiedler, H.-P., Zucchi, T. D. \& Bull, A. T. (2012). Verrucosispora maris sp. nov., a novel deep-sea actinomycete isolated from a marine sediment which produces abyssomicins. Antonie van Leeuwenhoek 101, 185-193. 
8. Kim, S.-J., Weon, H.-Y., Kim, Y.-S. \& Kwon, S.-W. (2011). Cohnella soli sp. nov. and Cohnella suwonensis sp. nov. isolated from soil samples in Korea. J Microbiol 49, 1033-1038.

9. Paster, B. J. (2011). Family II. Brachyspiraceae. In Bergey's Manual of Systematic Bacteriology, 2nd edn, vol. 4, p. 531. Edited by N. R. Krieg, J. T. Staley, D. R. Brown, B. P. Hedlund, B. J. Paster, N. L. Ward, W. Ludwig \& W. B. Whitman. New York: Springer.

10. Poli, A., Laezza, G., Gul-Guven, R., Orlando, P. \& Nicolaus, B. (2011). Geobacillus galactosidasius sp. nov., a new thermophilic galactosidase-producing bacterium isolated from compost. Syst Appl Microbiol 34, 419-423.

11. Rameshkumar, N., Gomez-Gil, B., Spröer, C., Lang, E., Dinesh Kumar, N., Krishnamurthi, S., Nair, S. \& Roque, A. (2011). Vibrio plantisponsor sp. nov., a diazotrophic bacterium isolated from a mangrove associated wild rice (Porteresia coarctata Tateoka). Syst Appl Microbiol 34, 487-493.

12. Rao, J. U., Rash, B. A., Nobre, M. F., da Costa, M. S., Rainey, F. A. \& Moe, W. M. (2012). Actinomyces naturae sp. nov., the first Actinomyces sp. isolated from a non-human or animal source. Antonie van Leeuwenhoek 101, 155-168.
13. Sorokin, D. Y., Panteleeva, A. N., Tourova, T. P., Kaparullina, E. N. \& Muyzer, G. (2011). Natronoflexus pectinivorans gen. nov. sp. nov., an obligately anaerobic and alkaliphilic fermentative member of Bacteroidetes from soda lakes. Extremophiles 15, 691-696.

14. Suzuki, R., Zhang, Y., lino, T., Kosako, Y., Komagata, K. \& Uchimura, T. (2010). Asaia astilbes sp. nov., Asaia platycodi sp. nov., and Asaia prunellae sp. nov., novel acetic acid bacteria isolated from flowers in Japan. J Gen Appl Microbiol 56, 339-346.

15. Tanasupawat, S., Kommanee, J., Yukphan, P., Moonmangmee, D., Muramatsu, Y., Nakagawa, Y. \& Yamada, Y. (2011). Gluconobacter uchimurae sp. nov., an acetic acid bacterium in the $\alpha$-Proteobacteria. J Gen Appl Microbiol 57, 293-301.

16. Watanabe, Y., Nagai, F. \& Morotomi, M. (2012). Characterization of Phascolarctobacterium succinatutens sp. nov., an asaccharolytic, succinate-utilizing bacterium isolated from human feces. Appl Environ Microbiol 78, 511-518.

17. Zamora, L., Fernández-Garayzábal, J. F., Palacios, M. A., Sánchez-Porro, C., Svensson-Stadler, L. A., Domínguez, L., Moore, E. R. B., Ventosa, A. \& Vela, A. I. (2012). Chryseobacterium oncorhynchi sp. nov., isolated from rainbow trout (Oncorhynchus mykiss). Syst Appl Microbiol 35, 24-29. 